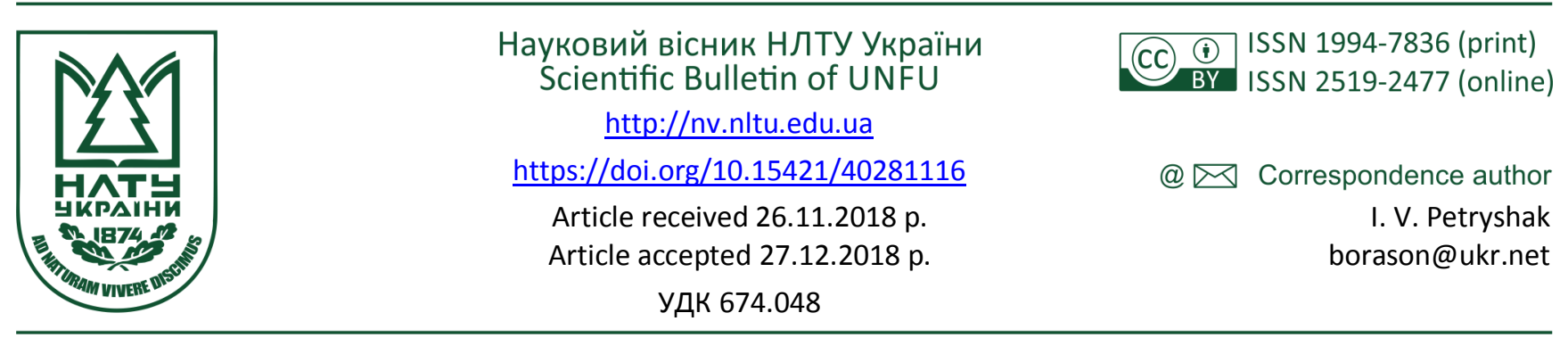

Ю. М. Губер, Ж. Я. Гуменюк, I. В. Петришак

Національний лісотехнічний університет України, м. Львів, Украйна

\title{
ЕКСПЕРИМЕНТАЛЬНІ ДОСЛІДЖЕННЯ ТЕПЛОВТРАТ ЧЕРЕЗ ОГОРОДЖЕННЯ СУШИЛЬНОЇ КАМЕРИ
}

\begin{abstract}
Наведено методику та результати дослідження кількості тепла, що втрачається через огородження сушильної камери за допомогою тепловізійного обстеження в умовах виробництва способом отримання термограми - зображення об'єкта в інфрачервоному спектрі, що показує картину розподілу температурних полів. Для визначення найбільших втрат тепла в сушильній камері застосовано тепловізор марки Fluke TI10. За наведеними тепловими знімками можна зробити висновки, що найбільші втрати тепла в основі сушильної камери - через фундамент. Також значні втрати є за периметром воріт для завантаження матеріалу та ревізійних дверей. Незначні втрати спостережено на бокових огородженнях. За результатами аналізу теплознімків найкритичнішими місцями виявлено периметр самих воріт та дверей, що пояснено властивостями використовуваних матеріалів та їх конструкцією: в місцях прилягання до стін сушильної камери всі елементи виготовлені 3 металу, який $є$ добрим провідником тепла і поганим теплозберігаючим матеріалом. Сама конструкція не допускає можливості застосування менш надійних енергозберігаючих матеріалів. Для теплоізоляції застосовують алюмінієві касети 3 теплоізолювальним наповнювачем - імпрегнованою мінеральною ватою. Для зменшення втрат тепла можливим є збільшення теплоізолювального шару та уникнення в такий спосіб теплових містків у конструкції камери. Для порівняння проведено розрахунки для теплоізолювального шару товщиною 100 і 150 мм. За результатами досліджень найбільшу економію від збільшення товщини теплоізоляційного шару спостережено в холодні пори року: від 1979 до 2282 кВт-год за один цикл процесу сушіння. Втрати теплової енергії залежать від середньої температури в камері. На останніх етапах процесу сушіння, де температура найвища, спостережено найбільший ефект від збільшення теплоізоляційного шару - від 1,92 до 3,12 кВт на годину. Зменшення втрат тепла через огородження із збільшенням товщини теплоізоляційного шару від 100 до 150 мм становить $32 \%$.

Ключові слова: сушильна камера; кількість тепла; теплоізоляційний шар; енергозбереження; тепловізор; тепловізійне обстеження; термографія.
\end{abstract}

Вступ. Філософія енергозбереження на рівні підприємства спрямована на забезпечення техніко-економічних параметрів виробництва й підвищення загальної ефективності функціонування. Особливої актуальності для суб'єктів господарювання набуває можливість впливати на собівартість продукції за рахунок її енергетичної складової. Енергозберігаючі технології дають змогу зменшити кількість енергії як теплової, так і електричної безпосередньо на процес сушіння, як на найбільш енергомісткий серед процесів деревооброблення (Leko, 2018; Bilei et al., 2013).

Одним із сучасних методів діагностування $є$ тепловізійне обстеження - отримання термограми - зображення об'єкта в інфрачервоному спектрі, що показує картину розподілу температурних полів. Тепловізор може виявити області витоків тепла в камері, неправильність функціонування опалювальних систем, систем охолодження або обігрівання чи кондиціонування повітря. Тепловізори виявляють випромінювання в інфра-

червоному діапазоні електромагнітного спектра (90014000 нанометрів).

Мета дослідження - визначення кількості теплоти, що втрачається через огородження сушильної камери із застосуванням тепловізійного обстеження.

Методика дослідження. Експериментальні дослідження проводили у виробничих умовах із використанням сушильної камери польської фірми LE.KO LK-ZDR50. Сушильну камеру призначено для сушіння деревини конвективним способом 3 об'ємом завантаження $\approx 50$ $\mathrm{m}^{3}$ за $35 \%$ заповнення штабеля матеріалом. Виготовляють 3 алюмінієвих сплавів та нержавіючої сталі. Теплоносій - гаряча вода 3 температурою $75-95^{\circ} \mathrm{C}$ на вході в сушарку. Габаритні розміри камери: ширина $-7,0$ м, глибина $-7,5$ м, висота $-5,3$ м. Несні каркасні конструкціїпрофілі $з$ нержавіючої сталі та алюмінієвих сплавів у формі зварних рамних конструкцій, які під час монтажу кріплять одна до одної болтовим з'єднанням. Застосовані матеріали стійкі до роботи в агресивному середовищі,

\section{Інформація про авторів:}

Губер Юрій Мирославович, канд. техн. наук, доцент, кафедра технологій захисту навколишнього середовища, деревини, безпеки життєдіяльності та соціальних комунікацій. Email: tszd@nltu.edu.ua

Гуменюк Жанна Ярославівна, асистент, кафедра технологій захисту навколишнього середовища, деревини, безпеки житєєіяльності та соціальних комунікацій. Email: Zhanna.humenyuk@nltu.edu.ua

Петришак Ігор Васильович, канд. техн. наук, доцент, кафедра технологій захисту навколишнього середовища, деревини, безпеки життєдіяльності та соціальних комунікацій. Email: borason@ukr.net

Цитування за Дсту: Губер Ю. М., Гуменюк Ж. Я., Петришак І. В. Експериментальні дослідження тепловтрат через огородження сушильної камери. Науковий вісник НЛтУ України. 2018, т. 28, № 11. С. 85-90.

Citation APA: Huber, Yu. M., Humeniuk, Zh. Ya., \& Petryshak, I. V. (2018). Experimental studies of heat loss through drying chamber enclosures. Scientific Bulletin of UNFU, 28(11), 85-90. https://doi.org/10.15421/40281116 
що створюється у процесі сушіння деревини (Baltfasad$\mathrm{SPb}, 2018$; Energy Strategy, n.d.).

Теплову ізоляцію сушильної камери складають касети 3 алюмінієвого листа товщиною 1,5 мм, заповнені мінеральною ватою, імпрегнованою речовинами, які не допускають поглинання вологи. Касети кріпляться до несучої конструкції гвинтами. Застосовані касети товщиною 100 мм забезпечують хорошу теплоізоляцію 3 коефіцієнтом теплопередачі $\mathrm{K} \approx 0,35 \mathrm{BT} / \mathrm{M}^{2} \cdot \mathrm{K}$. Зовні камера облицьована алюмінієвими профільними листами товщиною 0,8 мм. Камера оснащена воротами, що піднімаються вверх та відводяться у сторону за допомогою спеціального механізму. Конструкція полотна воріт аналогічна конструкції бокових стін камери. За периметром воріт застосовано ущільнення з силіконового профілю для герметичності дверей камери та довговічності (Ozarkiv et al., 2009, 2014). У задній стіні камери вмонтовано ревізійні двері, які забезпечують легкий доступ всередину камери без необхідного вивантаження матеріалу. Приплив свіжого та викидання відпрацьованого повітря в камері регулюється повітряними засувками по обидва боки вентиляторної рами, які повертаються на певний кут сервоприводами 3 безпечною напругою живлення 24 В.

Для визначення найбільших втрат тепла використовували тепловізор марки Fluke TI10, за допомогою якого можна побачити місця тепловтрат. Синій відтінок на теплових знімках відображає нижню половину шкали температур, тобто ділянки поверхні з незначними енерговитратами. Чорний колір відображає найнижчу тем- пературу (Bilei et al., 2013; Baltfasad-SPb, 2018; Ozarkiv et al., 2009). Червоний відтінок на теплових знімках відображає верхню половину шкали температур, тобто ділянку поверхні з високими енерговитратами. Білий колір відображає найтепліші ділянки, а також температуру, яка виходить за межі верхньої температурної шкали. Цифровими позначеннями на теплових знімках зазначали реальну температуру в місцях встановлення, що дає змогу показати різницю в різних місцях знімку, а також втрати тепла в цих місцях (Leko, 2018; Energy Strategy, n.d.; Ozarkiv et al., 2014). Значення температурної шкали та величини температурних точок зазначали в градусах Цельсія $\left({ }^{\circ} \mathrm{C}\right)$.

У камері висушували необрізні дубові пиломатеріали товщиною 50 мм. Параметри режиму сушіння навели в табл. 1.

Табл. 1. Параметри режиму сушіння

\begin{tabular}{|c|c|c|c|c|}
\hline \multirow{2}{*}{$\begin{array}{c}\text { Стадія } \\
\text { сушіння }\end{array}$} & \multicolumn{2}{|c|}{$\begin{array}{c}\text { Вологість } \\
\text { деревини } W, \%\end{array}$} & \multirow{2}{*}{$\begin{array}{c}\text { Температура } \\
\text { агента сушіння } \\
t_{c},{ }^{\circ} \mathrm{C}\end{array}$} & \multirow{2}{*}{$\begin{array}{c}\text { Психрометрич- } \\
\text { на різниця } \Delta t, \\
{ }^{\circ} \mathrm{C}\end{array}$} \\
\hline & $\begin{array}{r}\text { почат- } \\
\text { кова } W_{n}\end{array}$ & $\begin{array}{c}\text { кінцева } \\
W_{\kappa} \\
\end{array}$ & & \\
\hline 1 & 80 & 72 & 30 & 2,6 \\
\hline 2 & 72 & 53 & 30 & 2,8 \\
\hline 3 & 53 & 42 & 30 & 2,9 \\
\hline 4 & 42 & 31 & 30 & 3,6 \\
\hline 5 & 31 & 27 & 34 & 4,2 \\
\hline 6 & 27 & 19 & 46 & 8,9 \\
\hline 7 & 19 & 8 & 64 & 23 \\
\hline
\end{tabular}

На тепловому знімку (рис. 1) припливно-витяжні канали виділяються яскравим червоним відтінком, оскільки повітря, яке виводиться з камери, має високу температуру.
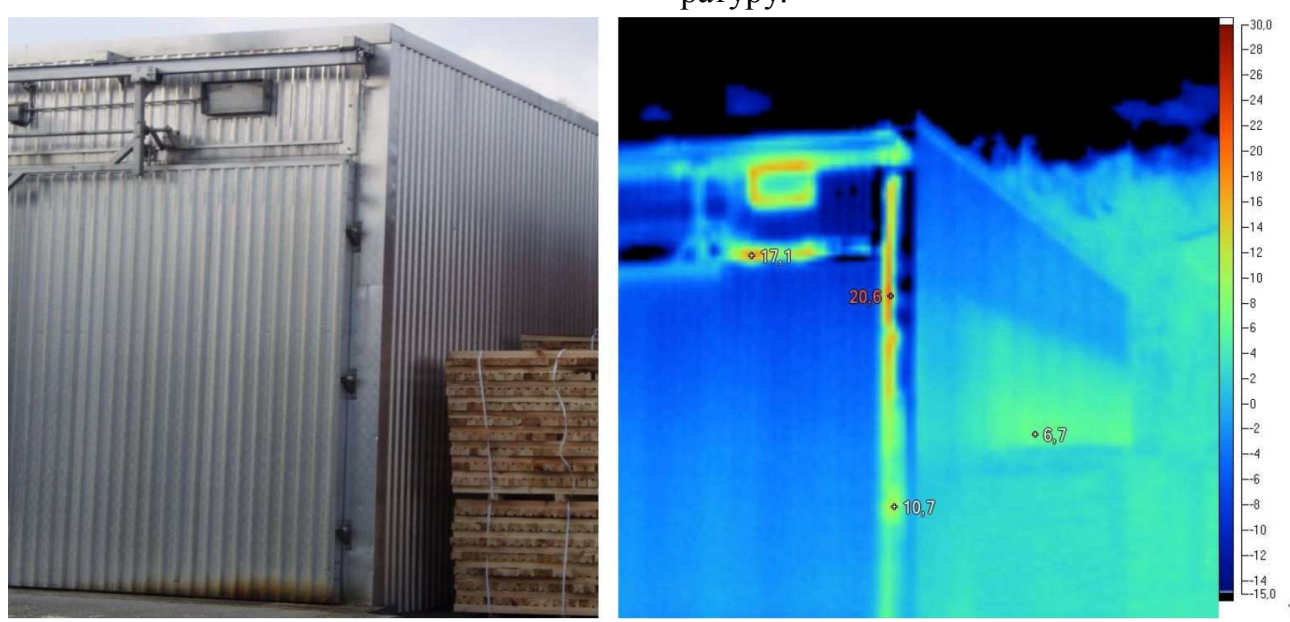

Рис. 1. Термографія фронтальної та бокової сторони сушильної камери

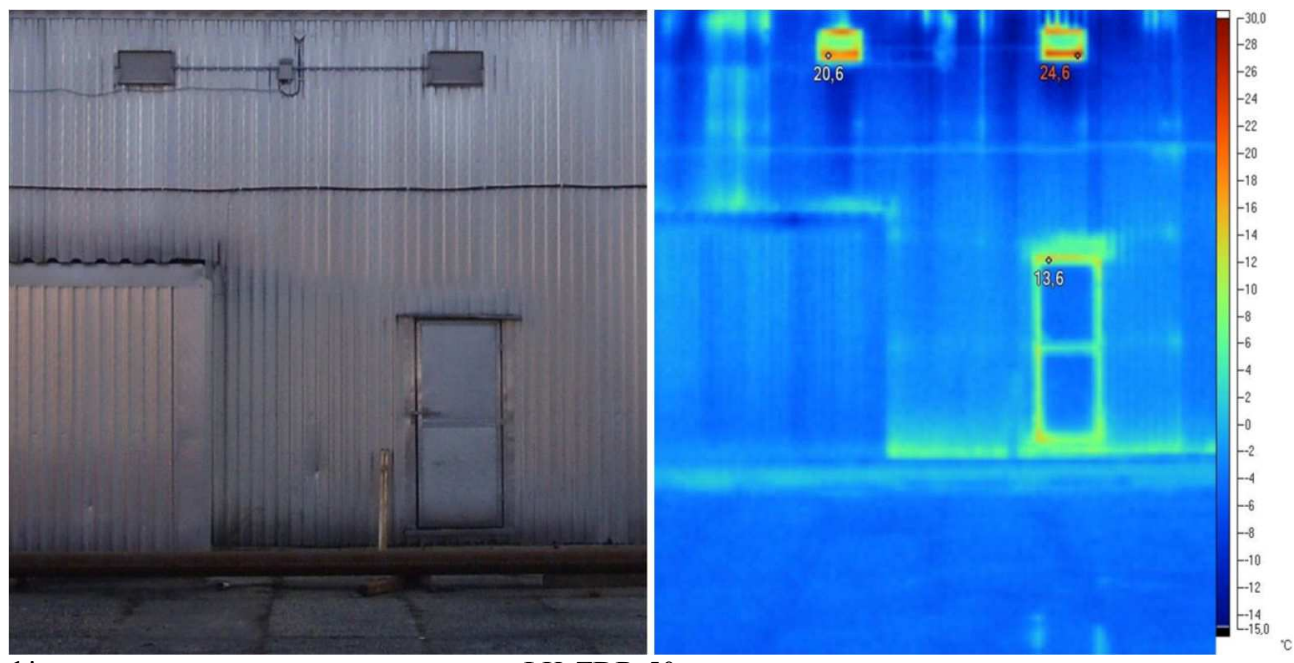

Pис. 2. Термографія тильної сторони сушильної камери LK-ZDR-50 
Тепловтрати найбільше проявляються в місцях стикування воріт із несучою конструкцією камери (рис. 2). У цих місцях розташовані температурні точки, які показують, що тепловтрати в різних частинах стикування $\epsilon$ різними. Тепловий знімок бокової сторони сушильної камери вказує місце з підвищеною температурою поверхні. На цій ділянці тепловтрати є більшими, оскільки розмір цієї ділянки займає значну частину стіни. Такі місця виникають у разі використання різних матеріалів утеплення, з різним коефіцієнтом теплопровідності, або внаслідок накопичення вологості в утеплювачі, що призводить до збільшення коефіцієнта теплопровідності та зумовлює більші тепловтрати.

Найтеплішими ділянками у верхній частині знімку є припливно-витяжні канали та рамка ревізійних дверей. На знімку можна спостерігати так звані "містки холоду" - місця стикування алюмінієвих касет.

Недоліки утеплення також виявлено в районі фундаменту сушильної камери (рис. 3). Зовнішнє утеплення фундаменту відсутнє. Це спричиняє нагрівання бетону, що має високий коефіцієнт теплопровідності. Для запобігання тепловтрат фундаменту найчастіше використовують утеплення екструдованим пінополістиролом 3зовні. Цей матеріал має низький коефіцієнт теплопро- відності, добре зберігає тепло, його можна використовувати у місцях із високою вологістю.

Для запобігання подальших втрат теплоти через фундамент необхідно влаштовувати додатковий або основний шар термоізоляції та ущільнити прилягання каркасу камери до основи за допомогою пінного наповнювача або термоізоляції. Для зменшення тепловтрат через ревізійні двері доцільно додатково змонтувати ущільнювач за їхнім контуром у місці прилягання до каркасу. Часткові втрати тепла відбуваються через бокові стіни і для запобігання втрат варто збільшити товщину теплоізолювального шару.

Найкритичнішими місцями є периметр дверей та воріт (рис. 4). У місцях дотику до стіни сушильної камери всі елементи металеві та є хорошими провідниками тепла, що призводить до швидкого нагрівання із середини камери і передачу тепла назовні. У конструкції дверей та воріт за периметром використовують профіль для надання жорсткості об'єкта та утримування теплоізоляційного матеріалу - мінеральної вати, яка є утеплюва-

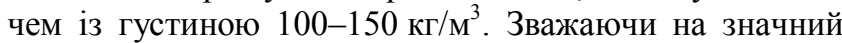
розмір воріт використання широкого металевого профілю, зрозуміло, що тепловтрати в місцях дотику до стіни будуть значними.
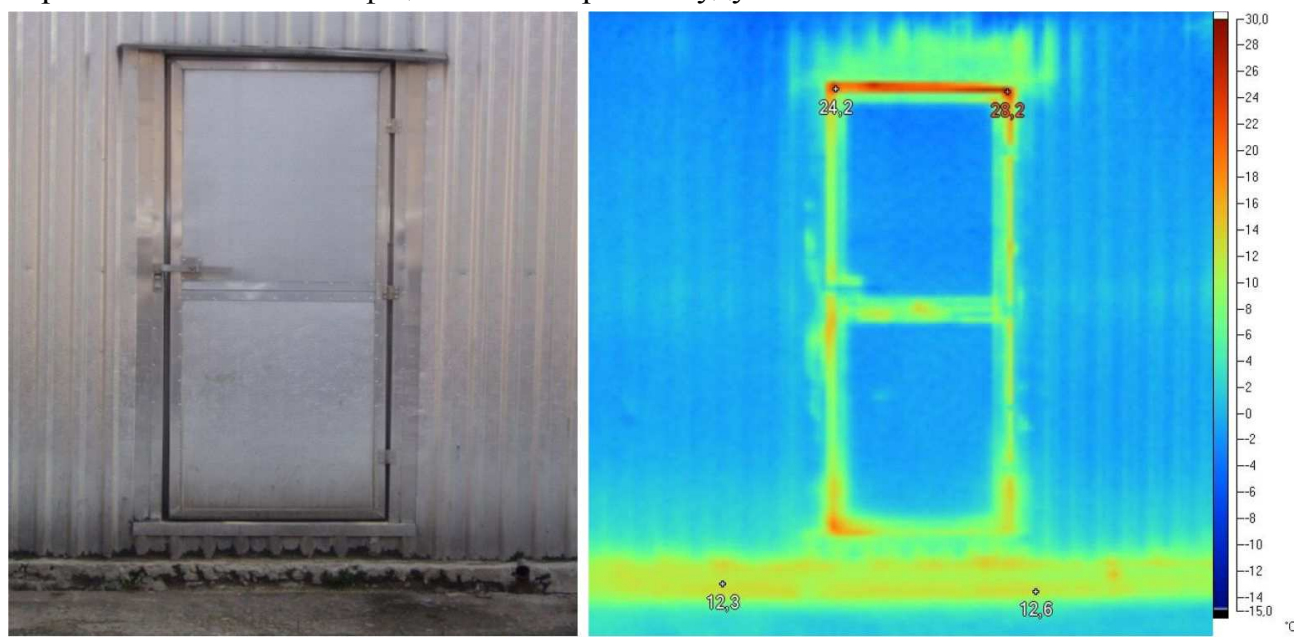

Рис. 3. Термографія фундаменту та конструкції ревізійних дверей сушильної камери
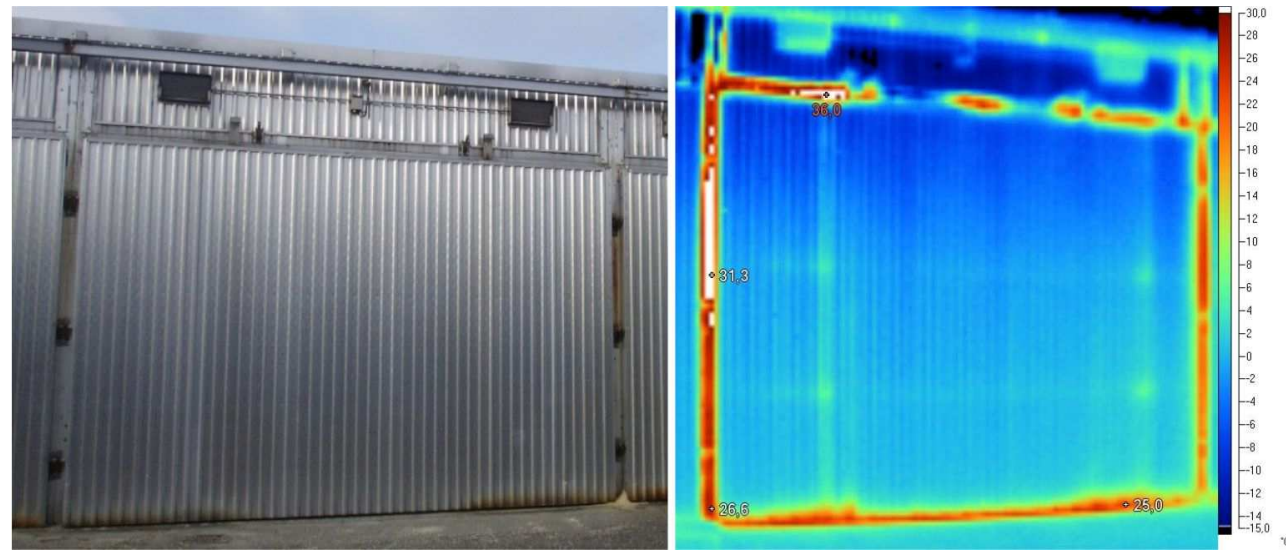

Рис. 4. Термографія воріт сушильної камери LK-ZDR-50

Для зменшення втрат тепла через бокові огородження сушильної камери можливим є збільшення теплоізоляційного шару та уникнення теплових містків у конструкції (рис. 5).

Втрати тепла через огородження камери визначали за формулою

$$
\sum Q_{o z}=\sum F_{o 2} \cdot K\left(t_{c}-t_{0}\right) \cdot 10^{-3} .
$$

Середню температуру в камері визначили за формулою:

$$
t_{c}=\frac{t_{1}+t_{2}}{2} .
$$

Коефіцієнт теплопередачі багатошарових огороджень:

$$
k=\frac{1}{\frac{1}{\alpha_{6 H}}+\frac{\delta_{1}}{\lambda_{1}}+\frac{\delta_{2}}{\lambda_{2}}+\frac{\delta_{3}}{\lambda_{3}}+\frac{1}{\alpha_{3 о в H}}} .
$$




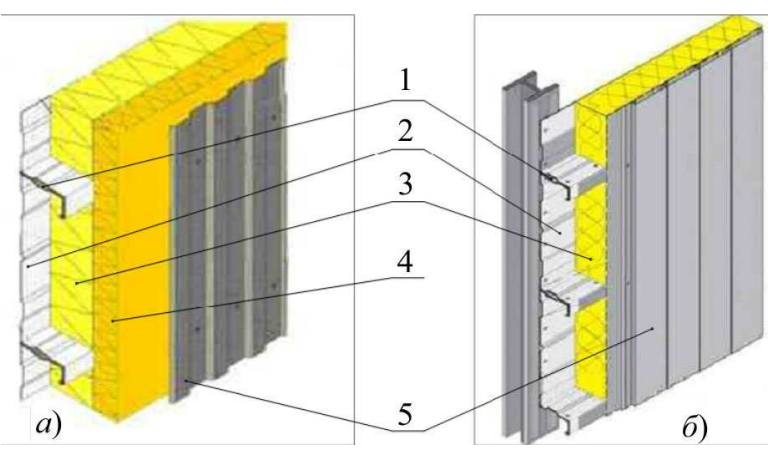

Рис. 5. Конструкція теплоізолювального шару (Bilei et al., 2013; Baltfasad-SPb, 2018): а) вдосконалена конструкція огородження;

б) конструкція, яку використовують у камері; 1) герметик;

2) металева касета; 3$)$ мінеральна вата $\left(50\right.$ кг $\left.\left./ \mathrm{M}^{3}\right) ; 4\right)$ ущільнена мінеральна вата
Усереднені метеорологічні параметри повітря для Львова, де встановлено сушильну камеру, наведено в табл. 2. Для порівняння втрат тепла через огородження проводили розрахунки для теплоізоляційного шару завтовшки 100 і 150 мм (табл. 3, 4). Економію тепла внаслідок збільшення товщини теплоізолювального шару наведено в табл. 5, 6 .

На рис. 6 і 7 зображено різницю втрат теплової енергії через огородження на різних стадіях процесу сушіння у лютому та різницю втрат теплової енергії через огородження камери протягом року на сьомій стадії процесу сушіння.

Табл. 2. Усереднені місячні метеорологічні параметри повітря, м. Львів

\begin{tabular}{|c|c|c|c|c|c|c|c|c|}
\hline Місяць & $t_{0}$ & $P_{0}$ & $\phi_{0}$ & $P_{H_{0}}$ & $d_{0}$ & $I_{0}$ & $\rho_{0}$ & $V_{n p 0}$ \\
\hline Січень & -3 & 764 & 81 & 327,8 & 2,50 & 3,21 & 1,29 & 0,78 \\
\hline Лютий & -9 & 769 & 77 & 327,8 & 1,60 & $-5,04$ & 1,32 & 0,76 \\
\hline Березень & 4 & 767 & 68 & 813,3 & 3,46 & 12,64 & 1,26 & 0,80 \\
\hline Квітень & 10 & 756 & 70 & 1227,9 & 5,39 & 23,53 & 1,23 & 0,82 \\
\hline Травень & 15 & 762 & 70 & 1708,2 & 7,53 & 33,96 & 1,21 & 0,84 \\
\hline Червень & 18 & 760 & 75 & 2063,8 & 9,78 & 42,69 & 1,19 & 0,85 \\
\hline Липень & 21 & 761 & 70 & 2494,1 & 11,05 & 48,97 & 1,18 & 0,86 \\
\hline Серпень & 19 & 762 & 74 & 2201,1 & 10,30 & 45,02 & 1,19 & 0,85 \\
\hline Вересень & 15 & 763 & 78 & 1708,2 & 8,40 & 36,16 & 1,21 & 0,84 \\
\hline Жовтень & 9 & 762 & 83 & 1150,6 & 6,00 & 24,04 & 1,23 & 0,82 \\
\hline Листопад & 5 & 764 & 86 & 873,9 & 4,71 & 16,77 & 1,25 & 0,80 \\
\hline Грудень & -4 & 763 & 87 & 327,8 & 2,70 & 2,70 & 1,30 & 0,78 \\
\hline
\end{tabular}

Табл. 3. Втрати тепла через огородження з товщиною теплоізоляційного шару 100 мм на різних стадіях процесу сушіння залежно від місяця року

\begin{tabular}{|c|c|c|c|c|c|c|c|c|c|c|c|c|c|}
\hline \multirow{2}{*}{$\begin{array}{l}\text { Стадія } \\
\text { режиму }\end{array}$} & \multirow{2}{*}{$\begin{array}{c}\text { Середня } \\
\text { температура } \\
\text { у камері, } t_{c}\end{array}$} & \multicolumn{12}{|c|}{ Втрати тепла через огородження, $Q_{o г}$, кВт } \\
\hline & & січень & лютий & березень & квітень & травень & червень & липень & серпень & вересень & жовтень & листопад & грудень \\
\hline 1 & 29,47 & 4,35 & 5,15 & 3,41 & 2,61 & 1,94 & 1,54 & 1,13 & 1,40 & 1,94 & 2,74 & 3,28 & 4,48 \\
\hline 2 & 29,56 & 4,36 & 5,17 & 3,43 & 2,62 & 1,95 & 1,55 & 1,15 & 1,42 & 1,95 & 2,76 & 3,29 & 4,50 \\
\hline 3 & 29,67 & 4,38 & 5,18 & 3,44 & 2,64 & 1,97 & 1,56 & 1,16 & 1,43 & 1,97 & 2,77 & 3,31 & 4,51 \\
\hline 4 & 29,74 & 4,39 & 5,19 & 3,45 & 2,65 & 1,98 & 1,57 & 1,17 & 1,44 & 1,98 & 2,78 & 3,32 & 4,52 \\
\hline 5 & 33,56 & 4,90 & 5,70 & 3,96 & 3,16 & 2,49 & 2,09 & 1,68 & 1,95 & 2,49 & 3,29 & 3,83 & 5,03 \\
\hline 6 & 45,51 & 6,50 & 7,31 & 5,56 & 4,76 & 4,09 & 3,69 & 3,29 & 3,55 & 4,09 & 4,89 & 5,43 & 6,64 \\
\hline 7 & 63,55 & 8,92 & 9,72 & 7,98 & 7,18 & 6,51 & 6,10 & 5,70 & 5,97 & 6,51 & 7,31 & 7,85 & 9,05 \\
\hline
\end{tabular}

Примітка: площа огороджень, $F_{0}=202,64$; коефіцієнт теплопередачі, $k=0,66$

Табл. 4. Втрати тепла через огородження з товщиною теплоізоляційного шару 150 мм на різних стадіях процесу сушіння залежно від місяця року

\begin{tabular}{|c|c|c|c|c|c|c|c|c|c|c|c|c|c|}
\hline \multirow{2}{*}{$\begin{array}{c}\text { Стадія } \\
\text { режиму }\end{array}$} & \multirow{2}{*}{$\begin{array}{c}\text { Середня } \\
\text { температура } \\
\text { у камері, } t_{c}\end{array}$} & \multicolumn{12}{|c|}{ Втрати тепла через огородження, $Q_{o z}$, кВт } \\
\hline & & січень & лютий & березень & квітень & травень & червень & липень & серпень & вересень & жовтень & пистопад & грудень \\
\hline 1 & 29,47 & 2,95 & 3,50 & 2,32 & 1,77 & 1,32 & 1,04 & 0,77 & 0,95 & 1,32 & 1,86 & 2,23 & 3,05 \\
\hline 2 & 29,56 & 2,96 & 3,51 & 2,33 & 1,78 & 1,33 & 1,05 & 0,78 & 0,96 & 1,33 & 1,87 & 2,24 & 3,05 \\
\hline 3 & 29,67 & 2,97 & 3,52 & 2,34 & 1,79 & 1,33 & 1,06 & 0,79 & 0,97 & 1,33 & 1,88 & 2,25 & 3,06 \\
\hline 4 & 29,74 & 2,98 & 3,53 & 2,34 & 1,80 & 1,34 & 1,07 & 0,80 & 0,98 & 1,34 & 1,89 & 2,25 & 3,07 \\
\hline 5 & 33,56 & 3,33 & 3,87 & 2,69 & 2,14 & 1,69 & 1,42 & 1,14 & 1,33 & 1,69 & 2,24 & 2,60 & 3,42 \\
\hline 6 & 45,51 & 4,42 & 4,96 & 3,78 & 3,23 & 2,78 & 2,50 & 2,23 & 2,41 & 2,78 & 3,32 & 3,69 & 4,51 \\
\hline 7 & 63,55 & 6,06 & 6,60 & 5,42 & 4,87 & 4,42 & 4,15 & 3,87 & 4,05 & 4,42 & 4,96 & 5,33 & 6,15 \\
\hline
\end{tabular}

Примітка: площа огороджень, $F_{0}=202,64$; коефіцієнт теплопередачі, $k=0,45$

Табл. 5. Різниця втрат тепла

\begin{tabular}{|c|c|c|c|c|c|c|c|c|c|c|c|c|}
\hline $\begin{array}{c}\text { Стадія } \\
\text { режиму }\end{array}$ & Січень & Лютий & Березень & Квітень & Травень & Червень & Липень & Серпень & Вересень & Жовтень & Листопад & Грудень \\
\hline 1 & 1,40 & 1,65 & 1,09 & 0,84 & 0,62 & 0,49 & 0,36 & 0,45 & 0,62 & 0,88 & 1,05 & 1,44 \\
\hline 2 & 1,40 & 1,66 & 1,10 & 0,84 & 0,63 & 0,50 & 0,37 & 0,45 & 0,63 & 0,88 & 1,06 & 1,44 \\
\hline 3 & 1,40 & 1,66 & 1,10 & 0,85 & 0,63 & 0,50 & 0,37 & 0,46 & 0,63 & 0,89 & 1,06 & 1,45 \\
\hline 4 & 1,41 & 1,67 & 1,11 & 0,85 & 0,63 & 0,50 & 0,38 & 0,46 & 0,63 & 0,89 & 1,06 & 1,45 \\
\hline 5 & 1,57 & 1,83 & 1,27 & 1,01 & 0,80 & 0,67 & 0,54 & 0,63 & 0,80 & 1,06 & 1,23 & 1,62 \\
\hline 6 & 2,09 & 2,34 & 1,78 & 1,53 & 1,31 & 1,18 & 1,05 & 1,14 & 1,31 & 1,57 & 1,74 & 2,13 \\
\hline 7 & 2,86 & 3,12 & 2,56 & 2,30 & 2,09 & 1,96 & 1,83 & 1,92 & 2,09 & 2,35 & 2,52 & 2,90 \\
\hline
\end{tabular}


Табл. 6. Економія теплової енергії

\begin{tabular}{|c|c|c|c|c|c|c|c|c|c|c|c|c|c|}
\hline $\begin{array}{l}\text { Стадія } \\
\text { режиму }\end{array}$ & Січень & Лютий & Березень & Квітень & Травень & Червень & Липень & Серпень & Вересень & Жовтень & Листопад & Грудень & \multirow{8}{*}{ 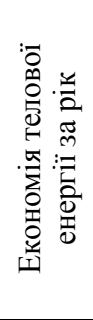 } \\
\hline 1 & 129,6 & 153,5 & 101,7 & 77,7 & 57,7 & 45,8 & 33,8 & 41,8 & 57,7 & 81,7 & 97,7 & 133,6 & \\
\hline 2 & 378,0 & 447,6 & 296,7 & 227,1 & 169,0 & 134,2 & 99,4 & 122,6 & 169,0 & 238,7 & 285,1 & 389,6 & \\
\hline 3 & 287,9 & 340,8 & 226,2 & 173,3 & 129,3 & 102,8 & 76,4 & 94,0 & 129,3 & 182,1 & 217,4 & 296,7 & \\
\hline 4 & 376,7 & 445,8 & 296,2 & 227,2 & 169,6 & 135,1 & 100,6 & 123,6 & 169,6 & 238,7 & 284,7 & 388,2 & \\
\hline 5 & 90,9 & 105,8 & 73,5 & 58,6 & 46,2 & 38,7 & 31,2 & 36,2 & 46,2 & 61,1 & 71,0 & 93,4 & \\
\hline 6 & 226,1 & 254,0 & 193,4 & 165,5 & 142,2 & 128,2 & 114,2 & 123,5 & 142,2 & 170,1 & 188,8 & 230,7 & \\
\hline 7 & 490,7 & 534,9 & 439,1 & 394,8 & 358,0 & 335,8 & 313,7 & 328,5 & 358,0 & 402,2 & 431,7 & 498,1 & \\
\hline $\begin{array}{l}\text { На } 1 \text { об. } \\
\text { камери }\end{array}$ & 1979,8 & 2282,4 & 1626,7 & 1324,1 & 1071,9 & 920,6 & 769,3 & 870,2 & 1071,9 & 1374,6 & 1576,3 & 2030,2 & \\
\hline
\end{tabular}

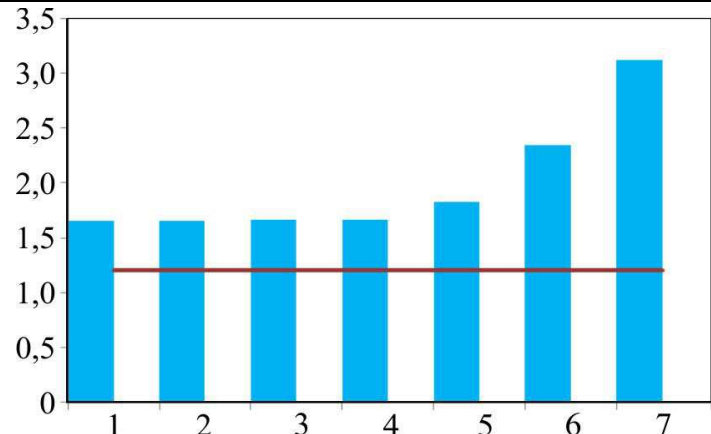

Рис. 6. Різниця втрат теплової енергії через огородження на різних стадіях процесу сушіння у лютому, кВт/год

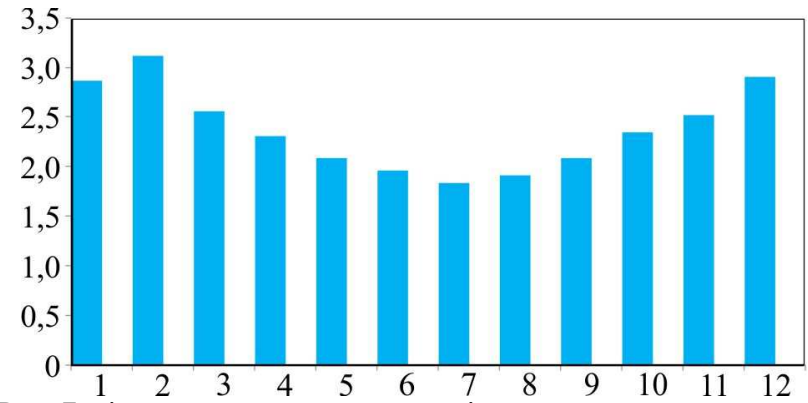

Рис. 7. Різниця втрат теплової енергії через огородження камери протягом року на 7-й стадії процесу сушіння, кВт/год

Висновки. За результатами досліджень можна зробити такі висновки:

1. Збільшення товщини теплоізоляції зменшує втрати тепла через огородження від 769 до 2282 кВТ-год за період процесу сушіння. Найбільшу економію спостерігаємо в холодні пори року від 1979кВт-год до 2282 кВт-год за
1 цикл сушіння. Найменшу користь від збільшення огородження у липні - 769 кВт-год.

2. Втрати теплової енергії залежать від середньої температури в камері. На останніх стадіях режиму сушіння, де температура найвища, найбільший ефект від збільшення теплоізоляційного шару - від 1,92кВт до 3,12 кВт на годину.

3. Середнє зменшення втрат тепла через огородження під час збільшення товщини теплоізоляційного шару від 100 мм до 150 мм становить $32 \%$.

\section{Перелік використаних джерел}

Baltfasad-SPb. (2018). OOO "Baltfasad-SPb" - fasadnye sistemy, sistemy fasadov, fasadnye raboty, montazh ventiliruemykh fasadov. Retrieved from: http://www.baltfasadspb.ru/ (Valid as of 15.08.2018). [In Russian].

Bilei, P. V., Petryshak, I. V., Sokolovskyi, I. A., \& Soroka, L. Ya. (2013). Teploobminni protsesy derevoobrobky: pidruchnyk. Lviv: ZUKTs, 260 p. [In Ukrainian].

Energy Strategy. (n.d.). Enerhetychna stratehiia Ukrainy na period do 2030 roku. Retrieved from: https://zakon.rada.gov.ua/laws/show/n0002120-13. (Enerhetychna stratehiia vtratyla chynnist na pidstavi Rozporiadzhennia KM № 605-r vid 18.08.2017). [In Ukrainian].

Leko. (2018). Proizvodstvo kamer dlia sushki drevesiny. Retrieved from: http://www.leko.polbiz.ru/ (Valid as of 15.08.2018). [In Russian].

Ozarkiv, I. M., Adamovskyi, M. H., Sokolovskyi, I. A., et al. (2014). Lisovyrobnychyi kompleks. Ekolohichni aspekty: monohrafiia. Lviv: ZUKTs, 264 p. [In Ukrainian].

Ozarkiv, I. M., Mysak, Y. S., Dzhyhyrei, V. S., Kiryk, M. D., Sokolovskyi, I. A., \& Miakush, I. I. (2009). Osnovy tekhnoekolohii: navch. posibnyk. Lviv: NVF "Ukrainski tekhnolohii", 336 p. [In Ukrainian].

Ю. М. Губер, Ж. Я. Гуменюк, И. В. Петришак

Национальный лесотехнический университет Украины, г. Львов, Украина

\section{ЭКСПЕРИМЕНТАЛЬНЫЕ ИССЛЕДОВАНИЯ ТЕПЛОПОТЕРЬ ИЗ-ЗА ОГРАЖДЕНИЯ} СУШИЛЬНОЙ КАМЕРЫ

\footnotetext{
Представлены методика и результаты исследований количества теплоты, теряемой через ограждения сушильной камеры с использованием тепловизионного обследования в производственных условиях путем получения термограммы - изображения объекта в инфракрасном спектре, что показывает картину распределения температурных полей. Для определения наибольших потерь теплоты в сушильной камере использован тепловизор марки Fluke TI10. Анализируя тепловые снимки можно утверждать, что наиболее ощутимые потери тепла в основе сушильной камеры - через фундамент. Большие потери наблюдаются также по периметру ворот для загрузки материала и ревизионную дверь. Менее ощутимые потери наблюдаются через боковые ограждения. По результатам анализа теплоснимков наиболее критическими местами по теплопотерям являются периметр ворот загрузки и ревизионная дверь, что напрямую зависит от конструкции и свойств используемого в конструкции материала: в местах примыкания к стенам сушильной камеры все конструкционные элементы изготовлены из металла, который хорошо проводит тепло и является плохим теплоизоляционным материалом. Конструкция сушильной камеры не допускает использование менее надежных, но более энергосохраняющих материалов. Для теплоизоляции используют алюминиевые кассеты с теплоизолирующим наполнителем - импрегнированной минеральной ватой. Для уменьшения потерь тепла возможно увеличение теплоизоляционного слоя, избежав таким образом тепловых мостов в конструкции сушильной камеры. С целью сравнения потерь тепла через ограждения проведены расчеты для теплоизолирующего слоя толщиной 100 и 150 мм. По результатам исследований наибольшая экономия от увеличения толщины изоляции наблюдается в холодное время года: от 1979 до 2282 кВт за один цикл процесса сушки. Потери тепловой энергии зависят от средней температуры в камере. На последних этапах процесса сушки, где температура наибольшего значения, наблюдается наиболее вы-
} 
сокий эффект от увеличения теплоизолирующего слоя - от 1,92 до 3,12 кВт в час. Уменьшение потерь тепла через ограждения с увеличением толщины теплоизолирующего слоя от 100 до 150 мм составляет $32 \%$.

Ключевые слова: сушильная камера; количество тепла; теплоизолирующий слой; энергосбережение; тепловизор; тепловизионное обследование; термография.

Yu. M. Huber, Zh. Ya. Humeniuk, I. V. Petryshak Ukrainian National Forestry University, Lviv, Ukraine

\section{EXPERIMENTAL STUDIES OF HEAT LOSS THROUGH DRYING CHAMBER ENCLOSURES}

The authors provide the methodology and results of the study of the amount of heat lost through the enclosure of the drying chamber by thermal examination in the production conditions by obtaining a thermogram, i.e. an image of the object in the infrared spectrum, which shows the picture of the distribution of temperature fields. Fluke TI10 thermal imager was used to determine the greatest heat losses in the drying chamber. Based on the thermal images taken, we can conclude that the greatest heat losses in the basis of the drying chamber - through the foundation. There are also significant losses behind the perimeter of the gate for material download and revision doors. Insignificant losses are observed on lateral fences. According to the results of the analysis of thermal images, the most critical places were the perimeter of the gates and doors themselves, which is explained by the properties of the materials used and their construction: in the places adjacent to the walls of the drying chamber, all the elements are made of metal, which is a good conductor of heat and poor heat insulation material. The drying chamber design itself does not allow using less reliable energy-saving materials. Aluminum cassettes with heat-insulating filler, impregnated mineral wool, are usually used for thermal insulation. To reduce the heat loss, it is possible to increase the insulating layer and thus avoid the thermal bridges in the chamber construction. Calculations have been performed for a heat-insulating layer ranging from 100 to $150 \mathrm{~mm}$ thick in order to provide a basis for comparison. According to research results, the greatest savings from increasing the thickness of the insulation layer are observed in the cold seasons: from $1979 \mathrm{~kW} / \mathrm{h}$ to $2282 \mathrm{~kW} / \mathrm{h}$ per one cycle of drying. Loss of thermal energy depends on the average temperature in the chamber. At the last stages of the drying process, where the temperature is the highest, we observed the greatest effect from the increase of the insulating layer ranging from $1.92 \mathrm{~kW} / \mathrm{h}$ to $3.12 \mathrm{~kW} / \mathrm{h}$. Reducing heat loss through the enclosures with an increase in the thickness of the insulation layer from 100 to $150 \mathrm{~mm}$ is $32 \%$.

Keywords: drying chamber; amount of heat; heat-insulating layer; energy conservation; thermal imager; thermal examination; thermography. 